\title{
Formulation of Plant Nutrient with Synbiotic Enhancement
}

\author{
S.P.V. Ananthan ${ }^{1}$, N. Ahmad ${ }^{1}{ }^{*}$, S.H. Noor ${ }^{1}$, M.S.A. Munaim ${ }^{1}$, S. Alias ${ }^{1}$, H. Hamid ${ }^{1}$, M. Mohammed ${ }^{1}$, A. Romli1 \\ ${ }^{1}$ Faculty of Chemical and Process Engineering Technology, Universiti Malaysia Pahang, 26600 Pahang, Malaysia.
}

\begin{abstract}
Oleochemical wastewater discharge from the industry into water sources is one of the main causes of water pollution. A proper treatment is required before the effluent is discharged to the environment. Since the oleochemical wastewater contains nutrients and probiotics that are good for plants, it could be used as a nutrient provider for the plants instead. Therefore, the formulation of synbiotic plant nutrients from this effluent is an effective way of using the oleochemical effluent. This study aimed to formulate the plant nutrients by using industrial wastewater, which contains the synbiotic enhancement and validating the significance of the formulated plant nutrients into three types of plants; Abelmoschus esculentus (Okra), Solanum Melongena (Brinjal), and Capsicum annuum (Chilli peppers). Synbiotic is a combination of both prebiotics and probiotics that benefit the host by stimulating the growth of a limited number of healthpromoting bacteria. To formulate the plant nutrient, the wastewater was filtered using a cotton cloth before the pre-biotics solution was added. Sample A (filtered wastewater was mixed with Sample B (prebiotics solution) by different percentages, namely F1 (100\%:0\%), F2 (75\%:25\%), F3 (50\%:50\%), F3 (25\%:75\%), 0\%:100\% (Sample A to Sample B respectively) and lastly, 50\%:50\% (Sample C (unfiltered wastewater) to Sample B respectively). The height of the plant and the number of leaves are measured weekly for four months. From the data, it can be seen that F3 gave significant results for the okra plant, in which it gains the highest height of plant compared to the other two plants. On the other hand, F6 give the best results for both the brinjal and the chilli plant where their leaves grow the highest from the second until the fourth month of plant growth. Hence, this research gives an added value to the wastewater, whereas the wastewater is used as the synbiotic plant nutrient enhancer and work best for the plants.
\end{abstract}

ARTICLE HISTORY

Received: 17 Jan. 2020

Revised: 13 Oct. 2020

Accepted: 26 Oct. 2021

\section{KEYWORDS}

Oleochemical

Wastewater

Synbiotic

Plant Nutrient

\section{INTRODUCTION}

The oleo-chemical industry in Malaysia is an off-shoot of the palm oil industry and it is a relatively new industry. Industrial Master Plan (IMP), 1986 has once stated that despite the anticipated importance of the oleo-chemical industry, great attention has been given to the pollution problems arising from the effluent produced [1]. The amount of effluent originating from the fatty acid plant and the oleo-chemical plant is about 52000 tons per annum. The volume of the effluent is forecast to increase with the construction of more oleo-chemical plants in the next ten years [2]. Nevertheless, oleo-chemical plants deal with manufacturing fatty products such as vegetables and animals, and the oleochemical sludge waste in this research comes from FPG Oleochemicals Sdn Bhd, which manufactures fatty alcohols, methyl esters, glycerine, and other organic chemicals mainly from palm plantation. Wastewaters from production contain fats, which after pre-treatment could be used in plant farming as fertilizers because they are biodegradable [3]. Due to the presence of nutrients such as nitrogen $(\mathrm{N})$, phosphorus $(\mathrm{P})$, and potassium $(\mathrm{K})$, it is possible to optimize and regulate N:P:K in the mixed wastewaters for plant nutrients [3].

Wastewaters are waterborne solids and fluids released into sewers. Wastewater incorporates broken up and suspended natural solids which are organically decomposable [4]. Wastewater can be characterized into four classes; domestic wastewater, industrial wastewater, infiltration or inflow, and stormwater [5]. Wastewater is considered a valuable asset rather than waste by researchers because it contains valuable contents such as gases and nutrients for energy productions and other purposes. Wastewater also contains nutrients such as nitrogen, phosphorus, and other essential elements to be used as fertilizers [6].

Synbiotic is a combination of both prebiotics (food for beneficial microorganisms) and good bacteria (beneficial microorganisms), which is also known as probiotics that benefit the host by stimulating the growth of a limited number of health-promoting bacteria, which improves host welfare, or plants in this study. Prebiotics is natural products that promote the growth of soil-microorganism and is commonly found in agro-industrial wastes such as sewage sludge, compost, humus, animal manure, and many more [7]. As for probiotics, it consists of beneficial microorganisms, which exert health-promoting and nutrient-mobilizing properties, as defined by Haas and Keel in [7]. Therefore, the synbiotics term is the combination of both prebiotics and probiotics that helps provide food for the plant microbes in order to survive 
for the plant growth. It has also been suggested that a combination of microbes and prebiotics (synbiotics) can be more efficient than either prebiotics or the microbes alone.

Plant nutrients are chemical elements and compounds necessary for plant growth, plant metabolism, and external supply. All nutrients have a crucial role in plant growth. There are macronutrients $(\mathrm{Ca}, \mathrm{Mg}, \mathrm{S}, \mathrm{N}, \mathrm{K}$, and $\mathrm{P}$ ) and micronutrients $(\mathrm{Fe}, \mathrm{B}, \mathrm{Cu}, \mathrm{Mn}, \mathrm{Cl}, \mathrm{Ni}, \mathrm{Mo}, \mathrm{Co}$, and $\mathrm{Zn}$ ) in which these nutrients enhance plant resistance power and regulate the mineral nutritional status of the plants [8]. The main nutrients needed for plant growth are Nitrogen $(\mathrm{N})$, Phosphorus (P), and Potassium (K). Each type of plant has a range of an optimum and a minimum level for the nutrient requirement. Plants start to show nutrients deficiency symptoms if the minimum level of nutrients requirement has not been reached. On the other hand, excessive nutrients could also cause poor growth due to toxicity. Therefore, a proper amount of nutrient application is essential [9-11].

Nevertheless, the study on the formulation of synbiotic plant nutrients using industrial wastewater is still scarce. Thus, this study aimed to formulate the synbiotic plant nutrients from the wastewater. The significance of the plant nutrient was validated through the height of the plant and the number of leaves on three different plants, which were Abelmoschus esculentus (Okra), Solanum Melongena (Brinjal), and Capsicum annuum (Chilli peppers) plants

\section{MATERIALS AND METHODS}

\section{Materials}

In this study, the oleochemical sludge waste sample was taken from FPG Oleochemical Sdn Bhd situated in Gebeng, Pahang. The prebiotic solution added to the wastewater was a commercialised product, named Prepecto which contains the nutrient ratio of nitrogen $(\mathrm{N})$ to phosphorus $(\mathrm{P})$ to potassium $(\mathrm{K})$ of 40: 10: 20.

\section{Preparation of Wastewater}

The wastewater used for F1, F2, F3, F4, and F5 were filtered using cotton cloth, while for F6 and F7, the wastewater was used without filtrating. Table 1 shows the formulation percentages for all the samples.

\section{Formulation of Plant Nutrients}

The wastewaters were added with the prebiotic solution according to the formulations in Table 1.

Table 1. The Formulation Percentages for Three Samples; Sample A, Sample B, Sample C

\begin{tabular}{cccc}
\hline \multirow{2}{*}{ Formulation } & $\begin{array}{c}\text { Sample A (Filtered } \\
\text { Wastewater, \%) }\end{array}$ & $\begin{array}{c}\text { Sample B (Prebiotics } \\
\text { Solution, \%) }\end{array}$ & $\begin{array}{c}\text { Sample C (Unfiltered } \\
\text { Wastewater, \%) }\end{array}$ \\
\hline F1 & 100 & 0 & 0 \\
F2 & 75 & 25 & 0 \\
F3 & 50 & 50 & 0 \\
F4 & 25 & 75 & 0 \\
F5 & 0 & 100 & 0 \\
F6 & 0 & 0 & 100 \\
F7 & 0 & 50 & 50 \\
\hline
\end{tabular}

\section{Injection of Plant Nutrients to The Plants}

The plant used in this research was planted from seedlings, and they were located outdoors with an average temperature of $32^{\circ} \mathrm{C}$. The plants were then watered every day, and the nutrient formulated was injected into the plant weekly for four months. Each plant was injected with $20 \mathrm{ml}$ of the respective formulated plant nutrient.

\section{Validation of Plant Nutrients on Three Different Types of Plants}

The plants used in this experiment were Okra, Brinjal, and Chilli. The validation was done weekly by measuring the height of the plant and the number of leaves of the plant. The measurement of plant height was done by measuring the plant from the topsoil upwards using a cotton rope which then was measured using a ruler.

\section{EXPERIMENTAL RESULTS}

Figure 1 and Figure 2 show the height of the plant against the formulations for $2^{\text {nd }}$ week, $2^{\text {nd }}$ month, $3^{\text {rd }}$ month and $4^{\text {th }}$ month. The plants in $2^{\text {nd }}$ week, $2^{\text {nd }}$ month, $3^{\text {rd }}$ month and $4^{\text {th }}$ month are shown in Figure 3.

An average of 78-79\% of nitrogen was found in inert form $\left(\mathrm{N}_{2}\right)$ in the atmosphere, which is not beneficial for plants and is therefore not directly taken by plants [12]. Therefore, the Nitrogen-fixing bacteria is essential to invade the host plant root hair, where it multiplies and stimulates the development of root nodules and plant cell enlargement $[13,14]$.

Moreover, the wastewater was also proven to have many characteristics of phosphorus solubilizing bacteria such as Pseudomonas, Bacillus, Escherichia Actinomycetes, and many other plant growth-promoting bacteria. Thus, they have a high tendency to become phosphorus solubilizing bacteria and act as a nutrient enhancer. The use of phosphate solubilizing bacteria as inoculants subsequently improves plant and crop yield uptake of phosphorus (P). Pseudomonas, 
Bacillus and Rhizobium strains are among the most effective solubilizers of phosphate $[15,16]$. Phosphorus is an essential nutrient in the biochemical reactions in plants, both as plant structure compounds and as a catalyst. It also helps to capture and convert the sun's energy into useful plant components. Phosphorus is also a vital component of Adenosinetriphosphate (ATP) which is also called the "energy unit' which helps to stimulate root development and improve crop quality $[17,18]$.

Furthermore, the potassium present in the prebiotics solution also plays a vital role in the growth of the plants. Potassium is an important plant nutrient and is necessary to grow and reproduce plants in large quantities. Potassium is required for biological processes for plant growth and development, such as protein synthesis, carbohydrate metabolism, and enzyme activation [19]. Potassium also helps in regulating the opening and closing of stomata which in return regulates the intake of $\mathrm{CO}_{2}$. Potassium triggers enzyme activation and is necessary for Adenosine Triphosphate (ATP) production [20,21]. It is important to have potassium in the plant as its deficiency could cause stunted growth, yellowing leaf, and an increase in susceptibility of the plant to diseases and pest infestation, which makes the plant vulnerable to damages under stress conditions [19].
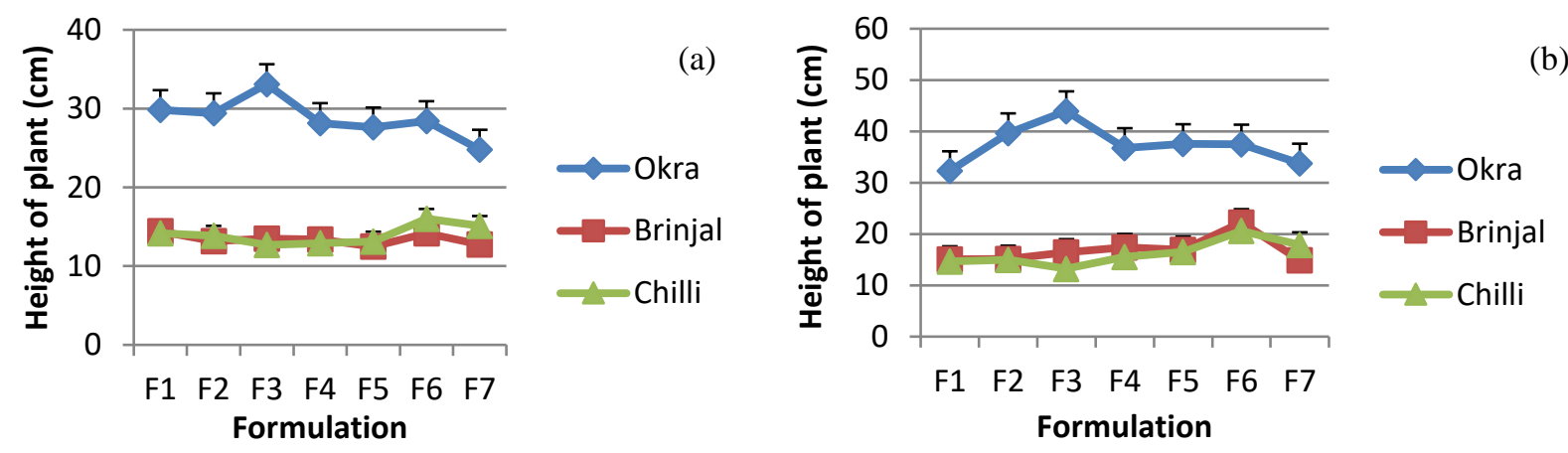

(b)

Figure 1. Height of Plants Versus Formulation of Nutrients for (a) $2^{\text {nd }}$ Week and (b) $2^{\text {nd }}$ Month
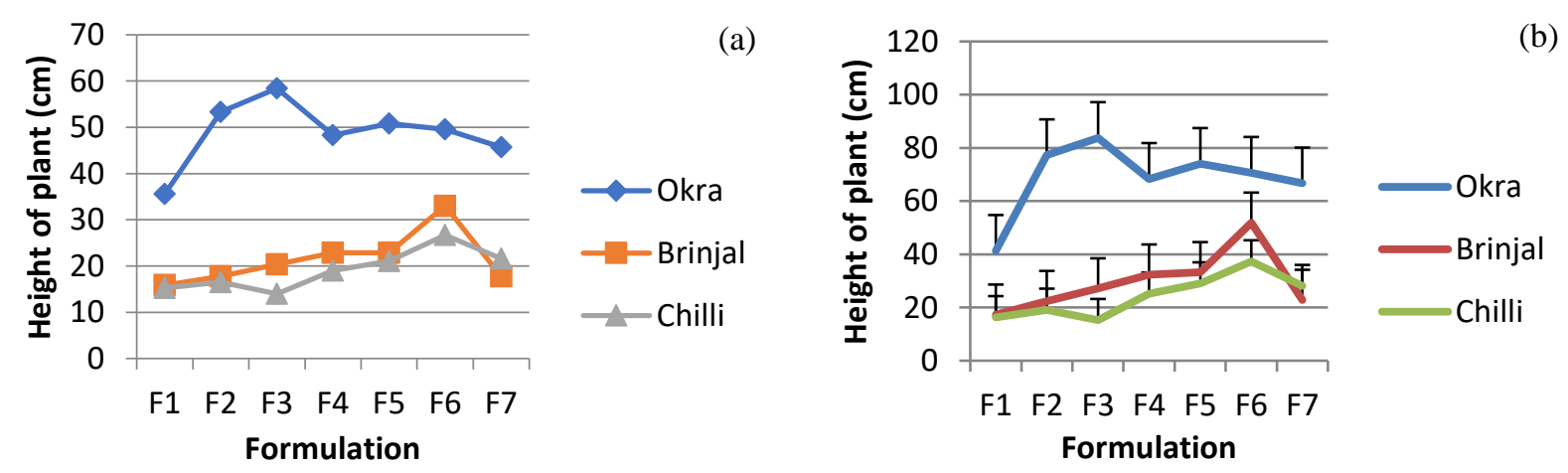

Figure 2. Height of Plants Versus Formulation of Nutrients for (a) $3^{\text {rd }}$ Month and (b) $4^{\text {th }}$ Month

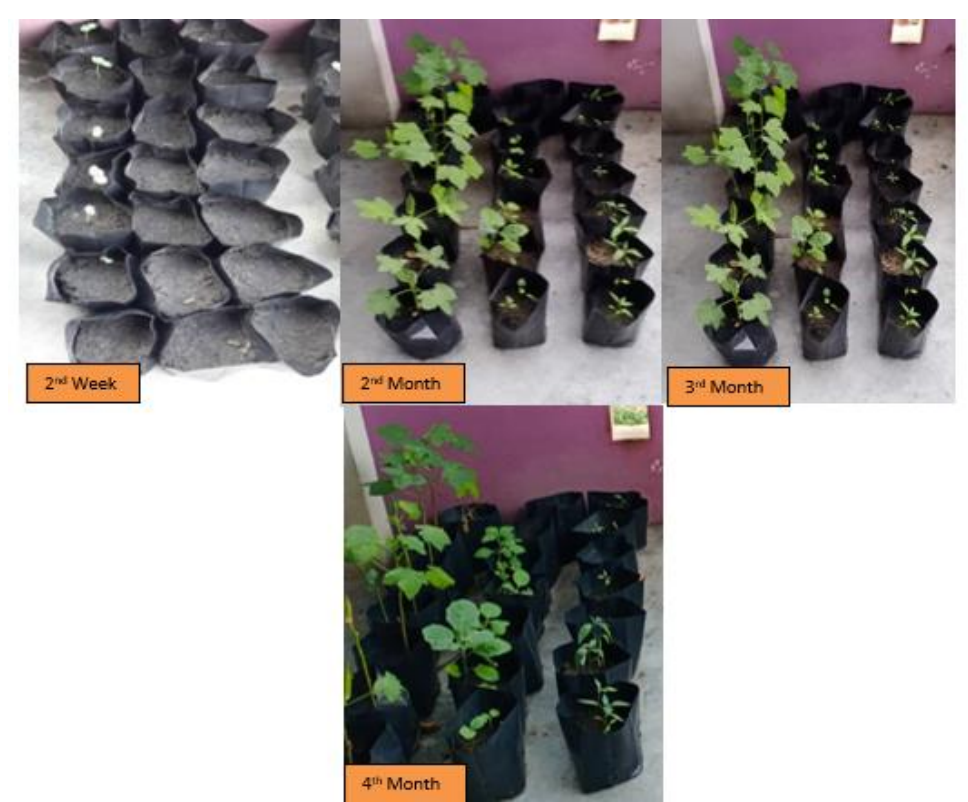

Figure 3. Plant Growth for $2^{\text {nd }}$ Week, $2^{\text {nd }}$ Month, $3^{\text {rd }}$ Month, and $4^{\text {th }}$ Month 


\section{CONCLUSION}

Overall, these findings suggest that the most suitable plant nutrient for the okra plant is F3, while F6 is suitable for both the brinjal and chili plant. The best duration for plant growth using the symbiotic approach is four months, as the height difference were more significant. Future studies on the current topic are therefore recommended. Firstly, the plants should be kept under greenhouse control to obtain an optimum condition for plant growth. Further characterization of the wastewater also should be done to identify the components present in the wastewater. Furthermore, the significance of the plant nutrients varies for the three different types of plants due to different requirements of nutrients by all three plants. Thus, it is best to use one type of plant only. Finally, plants with no addition of plant nutrients should be used to compare the significance of the plant nutrient with the plant growing in normal conditions without any plant nutrients.

\section{ACKNOWLEDGEMENT}

The authors would like to thank University Malaysia Pahang (UMP), Faculty of Chemical and Process Engineering Technology, through a local industrial research grant scheme No.: RDU192811.

\section{REFERENCES}

[1] R. A. Stephen. "Treatment of Industrial Oleochemical Wastewater Using Electrocoagulation Method,", no. June, pp. 1-14, 2015.

[2] Market Research.com. "Oleochemicals Market Size, Share \& Trends Analysis Report by Product (Fatty Acid, Glycerol, Fatty Alcohol), By Region (APAC, MEA, Europe, North America, CSA), and Segment Forecasts, 2019-2025," Grand View Research, 280, 2019, Retrieved from: https://www.marketresearch.com/Grand-View-Research-v4060/Oleochemicals-SizeShare-Trend-Product-12458973/.

[3] S. Zak, T. Rauckyte-Zak, and A. Laurinavicius, "The Influence of Treated Oleochemical Wastewater Applications on The Metal Speciation Forms in Soils," Journal of Environmental Engineering and Landscape Management., vol. 21, no. 2, pp. 85-95, 2013, doi: 10.3846/16486897.2013.773259.

[4] E. S. Ara, "Effect of Microwave Pre-Treatment of Thickened Waste Activated Sludge on Biogas Production from CoDigestion of Organic Fraction of Municipal Solid Waste," Waste Management \& Research, vol. 32, no. 1200-9, 2014, doi: $10.1177 / 0734242 X 14554641$.

[5] A. Sonune, and R. Ghate, "Developments in Wastewater Treatment Methods," Desalination., vol. 167, no. August, pp. 5563, 2004, doi:10.1016/j.desal.2004.06.113.

[6] Y. Li, "Wastewater is an Asset, With Nutrients, Energy and Precious Metals - and Scientists are Learning How to Recover Them," 2019, Retrieved from: https:/www.greenbiz.com/article/wastewater-asset-nutrients-energy-and-precious-metalsand-scientists-are-learning-how

[7] M. Vassileva, F.P. Elena, M. Eligio, and V. Nikolay, "Towards Better Understanding of the Interactions and Efficient Application of Plant Beneficial Prebiotics, Probiotics, Postbiotics and Synbiotics," Front. Plant. Sci.., vol. 11, no. 1068, 2020, doi: $10.3389 /$ fpls.2020.01068.

[8] H. El-Ramady, "Plant Nutrients and Their Roles Under Saline Soil Conditions," Plant Nutrients and Abiotic Stress Tolerance, pp. 297-324, 2018, doi: 10.1007/978-981-10-9044-8_13.

[9] K. Zeratsky, "What Are Probiotics and Prebiotics?," Mayo Clinic, 2020, Retrieved from: https://www.mayoclinic.org/healthylifestyle/consumer-health/expert-answers/probiotics/faq-20058065.

[10] G. C. Gervajio, T. S. Withana-Gamage, and M. Sivakumar, "Fatty Acids and Derivatives from Coconut Oil," Bailey's Industrial Oil and Fat Products., 2020, doi: 10.1002/047167849X.bio039.pub2.

[11] D. Mmereki, A. Baldwin, L. Hong, and B. Li, "The Management of Hazardous Waste in Developing Countries," Management of Hazardous Wastes, 2016, doi:10.5772/63055.

[12] S. J. Leghari, "Role of Nitrogen for Plant Growth and Development: A Review," Advances in Environmental Biology., vol. 10, no. 9, pp. 209-218, 2016, doi:10.1016/j.desal.2004.06.113.

[13] Britannica, The Editors of Encyclopaedia. "Nitrogen-fixing bacteria," Encyclopedia Britannica., 13 Jan. 2020, https://www.britannica.com/science/nitrogen-fixing-bacteria. Accessed 13 October 2021.

[14] Soiltech, Soil Technologies Corp. "How Nitrogen Fixing Bacteria Work," Agricultural., 5 September 2017, https://www.soiltechcorp.com/blog/how-nitrogen-fixing-bacteria-work/

[15] H. Rodriguez, and R. Fraga, "Phosphate Solubilizing Bacteria and Their Role in Plant Growth Promotion," Biotechnology Advances., vol. 17, no. 4-5, pp. 319-339, 1999, doi:10.1016/S0734-9750(99)00014-2.

[16] G. Kalayu. "Phosphate Solubilizing Microorganisms: Promising Approach as Biofertilizers," International Journal of Agronomy., vol. 2019, Article ID 4917256, 7 pages, 2019, doi:10.1155/2019/4917256.

17] Mosaic, "Phosphorus," 1 September 2019, https://www.cropnutrition.com/efu-phosphorus

18] Greenway Biotech, Greenway Biotech Inc., "What's the Function of Phosphorus (P) in Plants?," 29 November 2016, https://www.greenwaybiotech.com/blogs/gardening-articles/whats-the-function-of-phosphorus-p-in-plants

[19] M. Hasanuzzaman, "Potassium: A Vital Regulator of Plant Responses and Tolerance to Abiotic Stresses," Agronomy., vol. 8, no. 3, p. 31, 2018, doi:10.3390/agronomy8030031.

[20] Smart Fertilizer, Smart Fertilizer Software "Potassium in Plants and Soil," 12 February 2020, https://www.smartfertilizer.com/articles/potassium-in-plants

[21] K. Prajapati, “The Importance of Potassium in Plant Growth - A Review," Indian Journal of Plant Sciemces., vol. 1, no. $02-$ 03, pp. 177-186, 2012. 